\title{
Mechanisms Mediating Pituitary Adenylate Cyclase-Activating Polypeptide Depolarization of Rat Sympathetic Neurons
}

\author{
Matthew M. Beaudet, Rodney L. Parsons, Karen M. Braas, and Victor May \\ Department of Anatomy and Neurobiology, University of Vermont College of Medicine, Given Health Science Building, \\ Burlington, Vermont 05405
}

\begin{abstract}
The direct effects of pituitary adenylate cyclase-activating polypeptides (PACAP) on sympathetic neurons were investigated using rat superior cervical ganglion neurons. Electrophysiological and pharmacological analyses were used to evaluate PACAP modulation of sympathetic neuron membrane potentials and to investigate potential ionic and intracellular signaling mechanisms mediating the responses. More than $90 \%$ of the sympathetic neurons were depolarized by the PACAP peptides even when stimulated release was blocked, indicating that the PACAP peptides elicited primary responses in the postganglionic neurons. The response profile was consistent for activation of PACAP-selective $\mathrm{PAC}_{1}$ receptors: nanomolar concentrations of PACAP27 and PACAP38 were required to stimulate depolarization, whereas vasoactive intestinal peptide failed to evoke any response. Furthermore, depolarizations elicited by PACAP27 were reduced by the $\mathrm{PAC}_{1}$ receptor antagonist PACAP(6-38). Both sodium influx and inhibition of a potassium
\end{abstract}

current contributed to the peptide-induced depolarizations. Activation of neither pertussis toxin- nor cholera toxin-sensitive G-proteins was required for generation of the depolarizations. CAMP and diacylglycerol production and activation of protein kinase $A$ or protein kinase $\mathrm{C}$ also were not requisite for the responses. By contrast, phospholipase C (PLC)-dependent inositol 1,4,5-triphosphate $\left(\mathrm{IP}_{3}\right)$ synthesis was crucial to the PACAP-mediated depolarizations. Although calcium release from $\mathrm{IP}_{3}$-sensitive stores was not required for the PACAP-induced responses, inhibition of $\mathrm{IP}_{3}$ receptors reduced the depolarizations. Thus, among the many signal transduction pathways coupled to the $\mathrm{PAC}_{1}$ receptor, the PACAP-induced depolarization of sympathetic neurons appears to require activation of PLC and subsequent generation of $\mathrm{IP}_{3}$.

Key words: sympathetic; superior cervical ganglion; autonomic; pituitary adenylate cyclase-activating polypeptide; PACAP; Trp channel; $I P_{3}$
The primary preganglionic sympathetic neurotransmitter is acetylcholine, and a major noncholinergic stimulatory factor of sympathetic neurons has been hypothesized to belong to the vasoactive intestinal peptide (VIP) family of related peptides (Ip et al., 1982, 1983, 1985; Kawatani et al., 1985; Schwarzschild et al., 1989). Recently, pituitary adenylate cyclase-activating polypeptides (PACAP) have been suggested to be physiologically relevant regulators of sympathetic physiology. The PACAP precursor molecule is posttranslationally processed to produce either the $\alpha$-amidated 38 or 27 amino acid peptides PACAP38 or PACAP27 (Arimura, 1998). PACAP peptides not only demonstrate sequence homology with the VIP family of peptides, they also share receptors with VIP. The actions of VIP and PACAP on target tissues are mediated by at least three putative seventransmembrane G-protein-coupled receptor subtypes identified to date (Spengler et al., 1993; Svoboda et al., 1993; Harmar and Lutz, 1994; Journot et al., 1995; Rawlings and Hezareh, 1996). PACAP peptides are more potent than VIP in binding and stimulating multiple intracellular second messenger pathways at the PACAP-selective $\mathrm{PAC}_{1}$ receptor; in contrast, the $\mathrm{VPAC}_{1}$ and $\mathrm{VPAC}_{2}$ receptors exhibit approximate equal high affinity for PACAP27, PACAP38, and VIP, and may represent the prototypic VIP receptors solely coupled to adenylyl cyclase (Christophe, 1993; Harmar and Lutz, 1994; Arimura and Shioda, 1995; Journot et al., 1995).

\footnotetext{
Received April 10, 2000; revised July 17, 2000; accepted July 25, 2000.

This work was supported by National Institutes of Health Grants HD-27468 and NS-01636 (V.M.) and NS-23978 (R.L.P.), and American Hearth Association Grants 975043N (R.L.P.) and 94015540 (K.M.B.). We thank Dr. Jean Hardwick for technical advice during early phases of this work, Lei Zhang for design of some of the oligonucleotide primers, and Thomm Buttolph for technical support with the initial mouse Trp channel reverse transcription PCR. We also thank Drs. Mark Nelson and David Saffen for enlightening scientific discussions and guidance.

Correspondence should be addressed to Dr. Victor May, Department of Anatomy and Neurobiology, University of Vermont College of Medicine, Given Health Science Building, Burlington, VT 05405. E-mail: vmay@zoo.uvm.edu.

Copyright (C) 2000 Society for Neuroscience $0270-6474 / 00 / 207353-09 \$ 15.00 / 0$
}

Previously, we demonstrated potent and efficacious PACAP regulation of superior cervical ganglion (SCG) sympathetic neurotransmitter/neuropeptide expression (May and Braas, 1995; Braas and May, 1996, 1999). In accord with the predicted pharmacological response profile for the $\mathrm{PAC}_{1}$ receptor, PACAP27 and PACAP38 are more potent than VIP in stimulating SCG neuron neuropeptide $\mathrm{Y}$ and catecholamine release, production, and mRNA expression. Molecular characterization demonstrated SCG $\mathrm{PAC}_{1}$ receptor expression, and morphological studies suggested that nearly all of the principal sympathetic neurons expressed the $\mathrm{PAC}_{1}$ receptor but expressed neither of the VPAC receptors (May and Braas, 1995; Moller et al., 1997a,b; Nogi et al., 1997; Beaudet et al., 1998; May et al., 1998; Braas and May, 1999). Moreover, we demonstrated PACAP expression in a subpopulation of preganglionic sympathetic neurons projecting to the SCG (Beaudet et al., 1998). These results are consistent with the potent neurotrophic activities of PACAP peptides in promoting sympathoneuroblast survival and mitosis (DiCicco-Bloom and Deutsch, 1992; DiCicco-Bloom, 1996; Tanaka et al., 1996; Waschek, 1996; Lu et al., 1998). Together, these results provided substantial evidence establishing central roles for PACAP peptides in sympathetic neuron function and development.

PACAP peptides have been shown to depolarize several neuronal cell types (Lai et al., 1997; Braas et al., 1998; Shibuya et al., 1998). Thus, to gain a better understanding of the diverse roles of PACAP peptides in sympathetic neuron physiology, we have initiated electrophysiological and pharmacological studies to assess both the ionic mechanisms and potential second messenger pathways generating PACAP-induced membrane depolarizations. Both influx of sodium and reduced potassium currents contributed to the PACAP-induced depolarizations. Among the many signal transduction pathways coupled to the $\mathrm{PAC}_{1}$ receptor, the PACAP-induced depolarization of sympathetic postganglionic neurons appeared to require activation of phospholipase $\mathrm{C}$ (PLC) and subsequent generation of inositol 1,4,5-triphosphate $\left(\mathrm{IP}_{3}\right)$.

\section{MATERIALS AND METHODS}

Cell culture. Primary SCG neuron cultures were prepared as described previously (May and Braas, 1995; May et al., 1995). All methods involving 
Table 1. RT-PCR gene-specific primers

\begin{tabular}{|c|c|c|c|c|c|}
\hline Oligo & Specificity & Sequence & Position & $\begin{array}{l}T_{\mathrm{a}} \\
\left({ }^{\circ} \mathrm{C}\right)\end{array}$ & $\begin{array}{l}\text { Predicted product } \\
\text { size (bp) }\end{array}$ \\
\hline Trp1-1 & Rat Trp1 & 5'-CGTAAGCCCACCTGTAAGAAGATAA-3' & $1003-1027^{a}$ & & \\
\hline Trp1-2 & Rat Trp1 & 5'-CCAAGTAAAGGGAATTCATAACAAAG-3' & $1350-1375^{a}$ & 53.5 & 373 \\
\hline Trp2-1 & Rat Trp2 & 5'-AGCCAGCGGTAGTGCGTCGTCT-3' & $369-390^{b}$ & & \\
\hline $\operatorname{Trp} 2-2$ & Rat Trp2 & 5'-CTTAAACTCAGGCTCCTTCCGTGCA-3' & $757-781^{b}$ & 60.8 & 413 \\
\hline Trp3-1 & Rat Trp3 & 5'-TGTAACTATGGTGGTCGTTCTGCTCA-3' & $45-70^{c}$ & & \\
\hline $\operatorname{Trp} 3-2$ & Mouse Trp3 & 5'-TGATATCGTGTTGGCTGATTGAGAAT-3' & $2266-2291^{d}$ & 55.2 & 363 \\
\hline Trp4-1 & Rat Trp4 & 5'-CCTACTTGAATGCCGTGGAAAAG-3' & $220-242^{e}$ & & \\
\hline Trp4-2 & Rat Trp4 & 5'-AAGATGATAGGCGTGATGTCTGG-3' & $540-562^{e}$ & 56.3 & 343 \\
\hline Trp5-1 & Rat Trp5 & 5'-AGTTTGTGGGAGCTACTATGTTTGG-3' & $23-47^{f}$ & & \\
\hline $\operatorname{Trp5}-2$ & Mouse Trp5 & 5'-TTCTTCTGTTAGCCCCTCATTTGTT-3' & $2601-2625^{g}$ & 54.9 & 431 \\
\hline Trp6-1 & Rat Trp6 & 5'-TCTTTCTGAAGTGAAGTCGGTGGTCA-3' & $33-58^{h}$ & & \\
\hline Trp6-2 & Mouse Trp6 & 5'-CTCCTTGTACTTGATTGTTTGTTGTGTGC-3' & $2344-2372^{i}$ & 55.1 & 465 \\
\hline $\operatorname{Trp} 7-1$ & Mouse Trp7 & 5'-GCAAAGTACAACCCAGCGTTTACCAC-3' & $1913-1938^{j}$ & & \\
\hline $\operatorname{Trp} 7-2$ & Mouse Trp7 & 5'-CACGTATCTCTTTATGAGCCGCTTCA-3' & $2445-2470^{j}$ & 57.2 & 558 \\
\hline
\end{tabular}

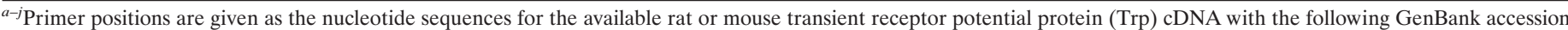

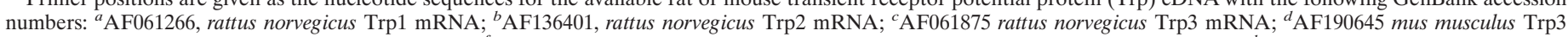

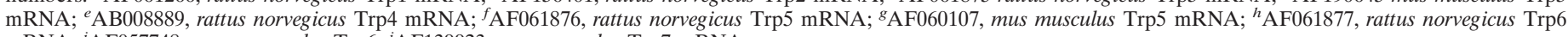
mRNA; ${ }^{i} \mathrm{AF} 057748 \mathrm{~m}$ mus musculus Trp6; ${ }^{j} \mathrm{AF} 139923$, mus musculus Trp7 mRNA.

animals were approved by the University of Vermont Institutional Animal Care and Use Committee. Untimed pregnant Sprague Dawley rats (Charles River, Quebec, Canada) were given commercial rat chow and tap water ad libitum and maintained on a $12 \mathrm{hr}$ light/dark cycle. Donor neonatal rats were rapidly decapitated, and the SCGs from four to five litters (typically 40-60 animals; $80-120$ ganglia) were dissociated enzymatically to produce a pooled population of cells. Cells were plated at an initia density of $3 \times 10^{3}$ neurons/ $/ \mathrm{cm}^{2}$ onto rat tail collagen-coated Aclar miniplates $\left(5 \mathrm{~cm}^{2}\right.$ dishes), treated with $10 \mu \mathrm{M}$ cytosine $\beta$-D-arabinof uranoside (Sigma, St. Louis, MO) to eliminate non-neuronal cells, and maintained in defined complete serum-free medium containing $50 \mathrm{ng} / \mathrm{ml}$ nerve growth factor (Becton Dickinson Labware, Bedford, MA) (May et al., 1995).

Bathing solutions and electrophysiological recordings. The Aclar miniplate neuron cultures were secured to a Sylgard-lined recording chamber and superfused continuously $(6 \mathrm{ml} / \mathrm{min})$ with either oxygenated Krebs' buffer containing (in mM): $121 \mathrm{NaCl}, 5.9 \mathrm{KCl}, 2.5 \mathrm{CaCl}_{2}, 1.2 \mathrm{MgCl}_{2}, 25$ $\mathrm{NaHCO}_{3}, 1.2 \mathrm{NaH}_{2} \mathrm{PO}_{4}$, and 8 glucose, pH 7.3, or a HEPES-buffered physiological solution containing (in $\mathrm{mM}$ ): $121 \mathrm{NaCl}, 5.9 \mathrm{KCl}, 2.5 \mathrm{CaCl}_{2}$, $1.2 \mathrm{MgCl}_{2}, 8$ glucose, and either 26 sodium HEPES, or 26 potassium HEPES, depending on the need to eliminate sodium ions, $\mathrm{pH} 7.35$, at $35-37^{\circ} \mathrm{C}$. The compositions of the bathing solutions were modified to investigate the nature of the ionic conductance underlying the PACAPinduced depolarization. A sodium-deficient solution was prepared by substituting $121 \mathrm{~mm} N$-methyl-D-glucamine chloride (NMG; Sigma) for $\mathrm{NaCl}$ in the potassium HEPES-buffered solution. To prepare a high potassium solution, the $\mathrm{KCl}$ concentration in the HEPES-buffered solution was increased to $20 \mathrm{~mm}$; because the sodium concentration was not modified, this resulted in a small increase in solution osmolarity $(\sim 9 \%)$. The osmolarity of the sodium-substituted HEPES-buffered solution was $13 \%$ less than the control Krebs'-buffered solution. This slight increase or decrease in osmolarity did not alter the morphological characteristics of the sympathetic neurons. For some experiments, tetrodotoxin (TTX; $300 \mathrm{nM}$; Sigma) or cadmium $(200 \mu \mathrm{M})$ was added to either the Krebs'- or HEPESbuffered physiological solutions.

SCG neurons were impaled with potassium citrate $(2 \mathrm{M})$-filled borosilicate microelectrodes $(60-80 \mathrm{M} \Omega)$, and the responses were recorded using an Axoclamp 2A amplifier (Axon Instruments, Foster City, CA). Recordings were made from single isolated neurons or neurons within small clusters (three to five neurons). Neurons were selected based on plasma membrane integrity and neuronal size; impalements were more stable from larger neurons (30-50 $\mu \mathrm{m}$ diameter). Membrane currents were measured in discontinuous single-electrode voltage-clamp mode with a sampling frequency of $8-10 \mathrm{kHz}$ and a $30 \%$ current $/ 70 \%$ voltage duty cycle. To analyze the voltage dependence of the peptide-induced membrane currents, current-voltage $(I-V)$ relationships were established by recording membrane currents elicited by computer-generated voltage ramps from -120 to $-30 \mathrm{mV}$ (pClamp Software, Version 6.0; Axon Instruments) at $25 \mathrm{mV} / \mathrm{sec}$ and a sampling rate of $500 \mathrm{~Hz}$. Data were collected on a Gould Brush 2400 chart recorder (Gould Instrument Systems, East Rutherford, NJ) and stored on a PCM recorder (A. R. Vetter Company, Rebersburg, PA); data were acquired digitally for subsequent analysis using the Clampfit program (pClamp 6.03, Axon Instruments).

Peptide and drug application. PACAP peptides and VIP were delivered by either chamber superfusion or local pressure application. In the superfusion studies, peptides were diluted from $100 \mu \mathrm{M}$ stocks to the final concentrations in bathing medium containing $1 \mathrm{mg} / \mathrm{ml}$ bovine serum albu- min to prevent peptide adsorbance to the perfusion tubing. For local pressure application (Picospritzer, General Valve, Fairfield, NJ), $50 \mu \mathrm{M}$ peptide in bath solution was released from small-diameter pipettes (5-10 $\mu \mathrm{m})$ positioned at a distance of $50-100 \mu \mathrm{m}$ from the cell. $N$-ethylmaleimide (NEM; $50 \mu \mathrm{M}$; Sigma), pertussis toxin (PTX; $500 \mathrm{ng} / \mathrm{ml}$; List Biological Laboratories, Campbell, CA), and cholera toxin (CTX; 500 $\mathrm{ng} / \mathrm{ml}$; List Biological Laboratories) were prepared from 1000-fold aqueous stocks. Final concentrations of $\mathrm{N}^{6}, \mathrm{O}^{2}$-dibutyryl cAMP (dBcAMP; 1 $\mathrm{mM}$ ) and 8-bromo cAMP (8-Br-cAMP; $1 \mathrm{mM}$; Boehringer Mannheim, Indianapolis, IN) were prepared directly in Krebs' buffer. Forskolin (10 $\mu \mathrm{M}), \mathrm{H}-89(25 \mu \mathrm{M}), \mathrm{U} 73122(5.6 \mu \mathrm{M})$, BimI $(2.5 \mu \mathrm{M})$, phorbol myristate acetate (PMA; $500 \mathrm{nM}$ ), 1-oleoyl-2-acetyl-sn-glycerol (OAG; $200 \mu \mathrm{M}$ ), xestospongin $\mathrm{C}$ and xestospongin $\mathrm{D}$ ( $\mathrm{XeC}$ and $\mathrm{XeD} ; 10$ and $20 \mu \mathrm{M}$, respectively) (all from Calbiochem-Novabiochem, La Jolla, CA), thapsigargin (100 nM; RBI, Natick, MA), and cyclopiazonic acid (CPA; $10 \mu \mathrm{M}$; Alexis Corp., San Diego, CA) were prepared from 1000-fold DMSO stocks. For $\mathrm{XeC}$ and $\mathrm{XeD}$, bovine serum albumin was deleted from the serum-free defined medium to obviate potential extraneous protein binding (Gafni et al., 1997). Sympathetic neurons were treated directly in the recording bath with $\mathrm{dBcAMP}$ or forskolin before pressure application (1 $\mathrm{sec})$ of PACAP27. SCG neurons were preincubated in defined medium containing $\mathrm{H}-89$, U73122, BimI, XeD, XeC, thapsigargin, or CPA for 20-30 min (acute treatments); additional cells were incubated in defined medium containing PTX, CTX, or PMA for $12-15 \mathrm{hr}$ (chronic treatments). After acute or chronic drug treatments, the cells were transferred to the recording chamber for peptide application. Cells were loaded with BAPTA using the membrane-permeant form of the chelator, BAPTA tetra(acetoxymethyl) ester (BAPTA/AM; $10 \mu \mathrm{M}$ for $15 \mathrm{~min}$ at $37^{\circ} \mathrm{C}$; Calbiochem-Novabiochem Corp.), and then maintained in defined medium without BAPTA/AM for $20-30 \mathrm{~min}$ at $37^{\circ} \mathrm{C}$ to allow cytoplasmic esterases to de-esterify the molecule. Inhibitors and activators were used at previously established concentrations shown to be effective in our SCG neuron in vitro preparations (May et al., 1995; Braas and May, 1999).

Messenger RNA analysis. Total RNA from brain, SCG, and SCG neuron cultures was prepared using RNA STAT-60 total RNA/mRNA isolation reagent (Tel-Test "B", Friendswood, TX) as described previously (May and Braas, 1995; Beaudet et al., 1998; Braas et al., 1998). The RNA from brain $(2 \mu \mathrm{g})$, individual SCG ganglion, or single culture well $\left(3 \times 10^{4}\right.$ neurons) was used to synthesize first-strand cDNA using SuperScript II reverse transcriptase and oligo dT primers with the SuperScript Preamplification System (Life Technologies, Gaithersburg, MD) in a $22 \mu 1$ final reaction volume. The cDNA was diluted $1: 10$, and $0.5 \mu$ l of the template was used for amplification; amplification of the cDNA templates was performed in a $13 \mu \mathrm{l}$ reaction volume consisting of $12.5 \mathrm{~mm}$ Tris- $\mathrm{HCl}, \mathrm{pH}$ 8.3 , containing $62.5 \mathrm{~mm} \mathrm{KCl}, 2.5 \mathrm{~mm} \mathrm{MgCl}, 200 \mu \mathrm{M}$ deoxynucleotide triphosphates, $0.5 \mu \mathrm{M}$ primers, $0.5 \mu \mathrm{l}$ of cDNA template, and $0.3 \mathrm{U}$ AmpliTaq Gold DNA polymerase (PE Applied Biosystems, Norwalk, CT) (May and Braas, 1995) with the cycling parameters as follows: (1) initial denaturation/enzyme activation, $95^{\circ} \mathrm{C}, 10 \mathrm{~min}$; (2) denaturation/enzyme activation, $94^{\circ} \mathrm{C}, 45 \mathrm{sec}$; annealing, transcript-specific temperature, $30 \mathrm{sec}$; $72^{\circ} \mathrm{C}$, $45 \mathrm{sec}(35 \mathrm{cycles}) ;$ ( 3 ) final extension, $72^{\circ} \mathrm{C}, 5 \mathrm{~min}$. Amplification was conducted using oligonucleotide primers specific for the identification of transient receptor potential (Trp) channel mRNA (Table 1); for each sample, the same cDNA template was used for amplification of the different Trp mRNA forms. The amplified products were resolved on $2 \%$ agaroseGelTwin II (J. T. Baker, Phillipsburg, NJ) gels and visualized by ethidium 


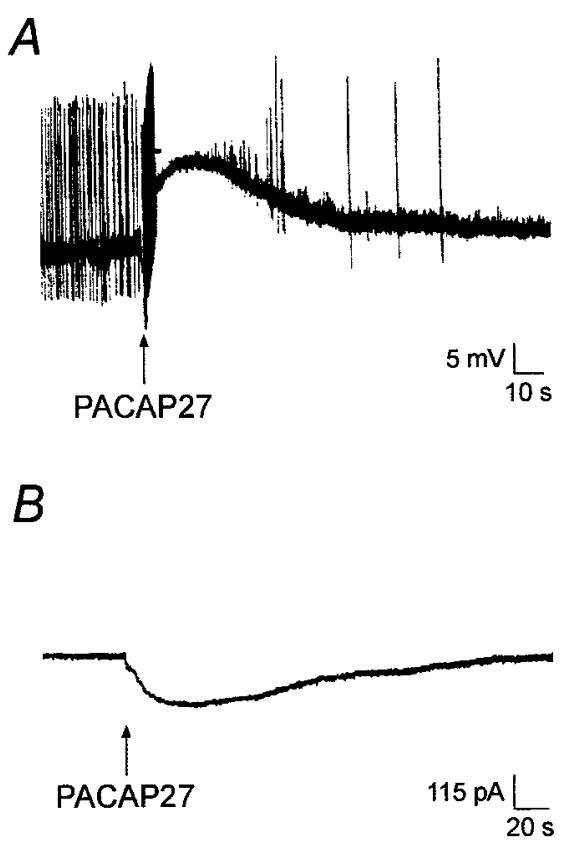

Figure 1. PACAP27 induces membrane depolarizations and inward currents in sympathetic neurons. $A$, PACAP-induced depolarization of a sympathetic neuron in response to $1 \mathrm{sec}$ pressure ejection of $50 \mu \mathrm{M}$ PACAP27 (arrow). B, In the presence of $300 \mathrm{nM}$ TTX, pressure application of $50 \mu \mathrm{M}$ PACAP27 to sympathetic neurons voltage-clamped to $-50 \mathrm{mV}$ revealed the current underlying the PACAP-induced depolarizations.

bromide staining under UV illumination. Complementary DNA synthesis in the absence of either RNA or reverse transcriptase, or amplification without template, primers, or DNA polymerase failed to yield products.

Curve fitting and statistical methods. All data represent mean neuron responses \pm SEM. After pressure application of peptide, the PACAPinduced depolarization recovered slowly such that after 3 and $10 \mathrm{~min}$ of wash, the current amplitude was $26 \pm 6 \%$ and $33 \pm 6 \%$ of the initial response, respectively. Thus, only one PACAP-induced response was determined per neuron to avoid changes in peptide sensitivity noted with multiple PACAP applications. PACAP concentration-dependence curves were generated assuming a single-site ligand binding isotherm using least squares regression analyses (SigmaPlot 4.0; SPSS Inc., Chicago, IL). Student's $t$ test or one-way ANOVA was used to determine differences among treatments; Newman-Keuls test was used in post hoc analysis to identify which treatments differed from the others. $p<0.05$ was considered significant.

\section{RESULTS}

\section{PACAP peptides depolarize SCG neurons}

Intracellular recordings were compiled from $>175$ cells from at least 25 different dissociated SCG neuron preparations. The average membrane resting potential recorded from the neonatal SCG neurons in vitro was $-55 \pm 0.7 \mathrm{mV}$. The mean membrane input resistance, determined from the application of $500 \mathrm{msec}$ hyperpolarizing $-0.1 \mathrm{nA}$ current pulses, was $153 \pm 24 \mathrm{M} \Omega(n=17)$; the majority of SCG neurons generated overshooting action potentials that were followed by membrane afterhyperpolarizations. Most of this action potential activity under resting conditions was eliminated during treatment with $200 \mu \mathrm{M}$ cadmium, indicating that it resulted primarily from synaptic activation.

Exposure of SCG neurons to $100 \mathrm{~nm}$ PACAP27 elicited membrane depolarizations in $>90 \%$ of the neurons examined, and the efficacy of PACAP27, applied by either pressure ejection or superfusion, on neuron depolarization was comparable. Pressure application of $50 \mu \mathrm{M}$ PACAP27 depolarized sympathetic neurons $12.6 \pm$ $0.7 \mathrm{mV}(n=35)$ (Fig. $1 A)$; superf usion of $100 \mathrm{~nm}$ PACAP27 for 30 sec depolarized SCG membranes $10.0 \pm 0.5 \mathrm{mV}(n=33)$. An increase in action potential activity commonly accompanied the initial phase of the PACAP-induced depolarization. A similar increase in firing rate occurred with comparable electrotonic de-

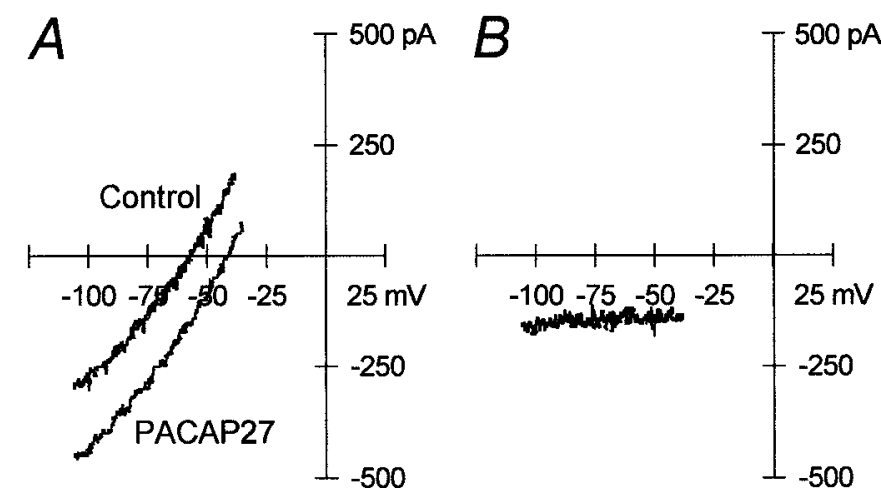

Figure 2. Current-voltage studies support PACAP modulation of multiple conductances. $A, I-V$ curves generated by voltage ramps from -120 to -30 $\mathrm{mV}$ at $25 \mathrm{mV} / \mathrm{sec}$ were measured before (Control) and during the peak (PACAP27) of PACAP-induced inward currents. B, Data denote differences in ramp currents before and after PACAP application. Representative data from seven separate experimental recordings.

polarization, suggesting that the change in activity resulted, at least in part, from membrane depolarization (data not shown).

To ensure that the PACAP-induced membrane depolarizations represented direct neuron responses to PACAP peptides and were not secondary to PACAP-induced release of other neuroregulators, the neurons were treated with either TTX or cadmium before peptide application to block stimulated neurotransmitter or neuromodulator secretion from adjacent terminals. In these experiments, superfusion of $100 \mathrm{~nm}$ PACAP27 in the presence of $300 \mathrm{~nm}$ TTX or $200 \mu \mathrm{M}$ cadmium depolarized SCG neurons $12.9 \pm 0.9 \mathrm{mV}(n=14)$ and $9.0 \pm 0.8 \mathrm{mV}(n=8)$, respectively, values that were similar to PACAP-induced depolarizations in the absence of TTX or cadmium. With 300 nм TTX added to the Krebs' solution to inhibit voltage-gated sodium channels and thus eliminate action potential generation, pressure application of $50 \mu \mathrm{M}$ PACAP27 onto 49 sympathetic neurons, voltage-clamped to $-50 \mathrm{mV}$, produced a mean inward current of $-146 \pm 9 \mathrm{pA}$ (Fig. $1 B$ ). These results provided direct evidence that PACAP peptides elicit primary responses in sympathetic postganglionic neurons.

To test whether the PACAP-induced depolarizations were associated with changes in the membrane resistance, $200 \mathrm{msec}$ constant current pulses that elicited $10-15 \mathrm{mV}$ hyperpolarizations were applied before and during PACAP application. Changes in the sizes of the transient hyperpolarizations were used to assess PACAP-induced changes in input resistance. The measurements of input resistance in the presence of PACAP were obtained after electrotonically nulling the PACAP-induced depolarization. The average change in membrane resistance was not different before $(185 \pm 35 \mathrm{M} \Omega)$ or at the peak of the depolarization $(185 \pm 30 \mathrm{M} \Omega)$. However, the PACAP-induced change in membrane resistance was variable: the membrane resistance decreased in four cells, increased in six cells, and was unchanged in one neuron, suggesting that a change in more than one ionic conductance very likely was involved in the generation of the PACAP-induced depolarization.

Results of voltage ramp studies supported the conclusion that the PACAP-induced depolarization resulted from modulation of more than one ionic conductance. Neurons were voltage-clamped to -50 $\mathrm{mV}$, and a slow voltage ramp $(25 \mathrm{mV} / \mathrm{sec})$ was applied over the voltage range of -120 to $-30 \mathrm{mV}$ before and at the peak of the inward current produced by a $1 \mathrm{sec}$ pressure application of PACAP27 (Fig. 2A). The PACAP-induced current was determined as the difference in the current recorded before PACAP application from the total current recorded in the presence of PACAP. The results demonstrated the presence of a PACAP-induced inward current over the entire voltage range, which could not be extrapolated to an apparent reversal potential (Fig. $2 B)(n=7)$. This observation was consistent with both activation of an inward current and inhibition of an outward current contributing to the PACAP-induced current. 


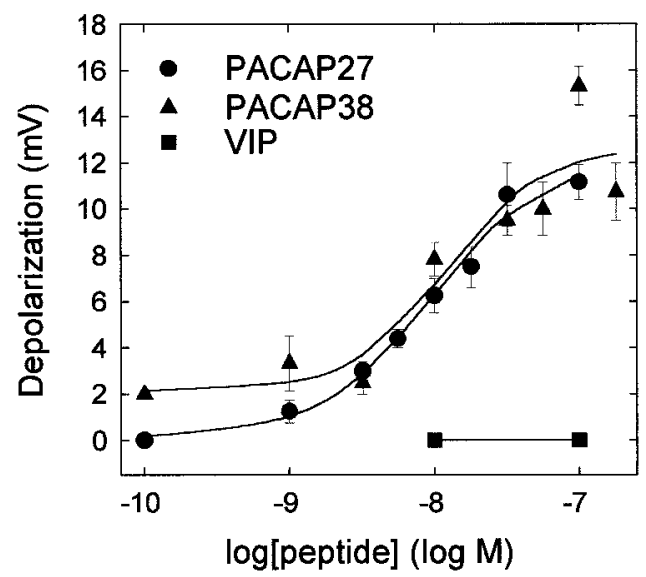

Figure 3. PACAP-induced SCG sympathetic neuron depolarizations are concentration-dependent. SCG neurons were superfused $(30 \mathrm{sec})$ with the indicated concentrations of PACAP27 $(\bullet)$, PACAP38 $(\mathbf{\Delta})$, or VIP $(\mathbf{\square})$, and neuronal depolarization was measured by intracellular recording. Maximal depolarizations of $\sim 10 \mathrm{mV}$ were attained with $32-100 \mathrm{~nm}$ PACAP peptides; PACAP27 and PACAP38 demonstrated identical half-maximal responses at $5 \mathrm{nM}$ peptide. The data represent the mean depolarization $(\mathrm{mV}) \pm \mathrm{SEM}$ ( $n=3-7$ neurons per concentration).

\section{PACAP-induced depolarizations are mediated by $\mathrm{PAC}_{1}$ receptors}

The concentration dependence of PACAP and VIP peptides in eliciting sympathetic neuron depolarizations was examined to establish whether the response profile was consistent for $\mathrm{PAC}_{1}$ receptor activation. Superfusion of varying concentrations of PACAP27 or PACAP38 onto sympathetic neurons currentclamped to $-50 \mathrm{mV}$ produced nearly identical concentrationresponse profiles (Fig. 3). Maximal depolarizations of $10-12 \mathrm{mV}$ were obtained with $32-100$ nM PACAP27 or PACAP38; halfmaximal responses were observed with $<10$ nM peptide. By contrast, VIP, which shares $>68 \%$ amino acid sequence identity with PACAP27, failed to elicit any depolarization at the concentrations tested (Fig. 3). This concentration-dependence profile for PACAP and VIP was indicative of PACAP-selective $\mathrm{PAC}_{1}$ receptor activation as a primary mechanism mediating the SCG depolarization.

To assess further the specificity of the PACAP-induced responses, sympathetic neurons were pretreated with $100 \mathrm{nM}$ PACAP(6-38) for $15 \mathrm{~min}$ before $100 \mathrm{~nm}$ PACAP27 or PACAP38 superfusion. PACAP $(6-38)$ reduced PACAP27-induced depolarizations $88 \%(1.5 \pm 2 \mathrm{mV} ; n=4 ; p<0.001)$. In contrast, PACAP(6-38) did not reduce PACAP38-elicited responses (13.3 \pm $2 \mathrm{mV} ; n=3 ; p=0.069)$. The pharmacological profile for PACAP and VIP in the concentration-dependence studies and the peptide antagonist effects were consistent with PACAP-selective $\mathrm{PAC}_{1}$ receptor activation as a primary mechanism mediating the SCG response.

\section{PACAP-induced depolarizations result from mechanisms requiring extracellular sodium and a reduction of a potassium current}

Experiments were undertaken to examine the ionic mechanisms underlying the observed PACAP-induced depolarizations. For sympathetic neurons, held at $-50 \mathrm{mV}$ and maintained in the HEPES-buffered physiological solution containing $300 \mathrm{~nm}$ TTX to eliminate action potential generation, a $1 \mathrm{sec}$ pressure application of $50 \mu \mathrm{M}$ PACAP27 elicited inward currents of $-142 \pm 16 \mathrm{pA}(n=$ 6). To investigate whether extracellular sodium contributed to the PACAP-induced currents recorded in these neurons voltageclamped at $-50 \mathrm{mV}$, the sodium ion concentration in the HEPESbuffered bathing solution was decreased by replacing sodium ions with the membrane-impermeant ion NMG (sodium-deficient solution). In the sodium-deficient solution, the PACAP-induced currents were reduced $\sim 70 \%$ from a control value of $-142 \pm 16 \mathrm{pA}$ to $-40 \pm 10 \mathrm{pA}(n=8 ; p<0.001)$ (Table 2). Therefore, sodium

\begin{tabular}{|c|c|}
\hline Solution & Current amplitude (pA) \\
\hline HEPES buffer & $-142 \pm 16(6)$ \\
\hline HEPES buffer $+20 \mathrm{~mm} \mathrm{KCl}$ & $-92 \pm 11(8)^{*}$ \\
\hline HEPES buffer + NMG & $-40 \pm 10(8)^{*}$ \\
\hline HEPES buffer $+20 \mathrm{~mm} \mathrm{KCl}+\mathrm{NMG}$ & $-12 \pm 3(10)^{*}$ \\
\hline
\end{tabular}

Sympathetic neurons were voltage-clamped at $-50 \mathrm{mV}$, and the current amplitude measured after PACAP27 $(1 \mathrm{sec})$ pressure application. The data represent the mean current amplitude \pm SEM. The numbers of cells tested are shown in parentheses. *Significantly different from control $(p<0.05)$.

influx appeared to be a critical factor contributing to the PACAPinduced currents.

Subsequent studies tested whether a component of the PACAPinduced currents could be attributed to inhibition of a potassium conductance. Initially, PACAP-induced currents were compared in cells maintained in the sodium-deficient NMG solution with control and elevated potassium concentrations. Elevation of the extracellular potassium concentrations from control levels of $5.9 \mathrm{~mm}$ to $20 \mathrm{~mm}$ was expected to shift the potassium equilibrium from approximately $-90 \mathrm{mV}$ to approximately $-50 \mathrm{mV}$ (Schofield and Ikeda, 1989) and thus should eliminate the contribution of any potassium current component in cells voltage-clamped at $-50 \mathrm{mV}$. The PACAP-induced current recorded from cells maintained in the HEPES-buffered sodium-deficient solution containing elevated potassium was $-12 \pm 3 \mathrm{pA}(n=10)$ (Table 2$)$, a value significantly less than that obtained in the sodium-deficient solution containing $5.9 \mathrm{~mm}$ potassium $(-40 \pm 10 \mathrm{pA} ; p=0.043)$.

To further appraise the contribution of the potassium conductance to the PACAP-induced current, the effects of elevating the external potassium concentration in the presence of sodium ions were also evaluated in complementary experiments. Increasing the external potassium concentration to $20 \mathrm{~mm}$ in the HEPES-buffered medium decreased the PACAP-induced inward currents by $\sim 35 \%$ $(-92 \pm 11 \mathrm{pA} ; n=8)$ (Table 2), compared with currents in the same solution containing $5.9 \mathrm{~mm}$ potassium $(-142 \pm 16 \mathrm{pA} ; n=6$; $p=0.002)$. Thus, in neurons voltage-clamped at $-50 \mathrm{mV}$, both sodium influx and inhibition of a potassium conductance contributed to the generation of the PACAP-induced currents.

To test whether calcium influx contributed to the residual PACAP-induced current present in the sodium-deficient solution, PACAP-induced currents were measured at $-50 \mathrm{mV}$ in neurons maintained in a HEPES-buffered, NMG-substituted $20 \mathrm{mM} \mathrm{KCl}$ solution with either no added calcium (nominally calcium deficient) or elevated calcium (5 mM). In sodium- and calcium-deficient solution, the PACAP-induced current was $-20 \pm 2.2 \mathrm{pA}(n=5)$; although larger, the current was not statistically different from that recorded when external calcium was $2.5 \mathrm{~mm}(-12 \pm 3.1 \mathrm{pA}, n=$ $10)$. When external calcium in the sodium-deficient solution was raised to $5 \mathrm{~mm}$, there was no measurable PACAP-induced current $(n=5)$; thus elevation of external calcium inhibited the residual inward current.

Experiments also were completed to establish whether elevation of external calcium levels to $5 \mathrm{~mm}$ inhibited PACAP-induced current in the presence of sodium. In preparations maintained in HEPES-buffered sodium solution with $20 \mathrm{~mm} \mathrm{KCl}$ and $5 \mathrm{~mm}$ calcium, the PACAP-induced current was $-34 \pm 10 \mathrm{pA}(n=5)$, an averaged current value significantly different from currents recorded in neurons maintained in comparable solution containing $2.5 \mathrm{~mm}$ calcium $(-92 \pm 11 \mathrm{pA}, n=8 ; p<0.01)$.

\section{Neither PTX- nor CTX-sensitive G-proteins are involved in the PACAP-induced depolarizations}

The $\mathrm{PAC}_{1}$ receptor belongs to group III of G-protein-coupled receptors and can initiate several transduction cascades, including the adenylyl cyclase and PLC signaling pathways (Fig. 4) (Absood et al., 1992; Deutsch and Sun, 1992; Hashimoto et al., 1993; Spen- 


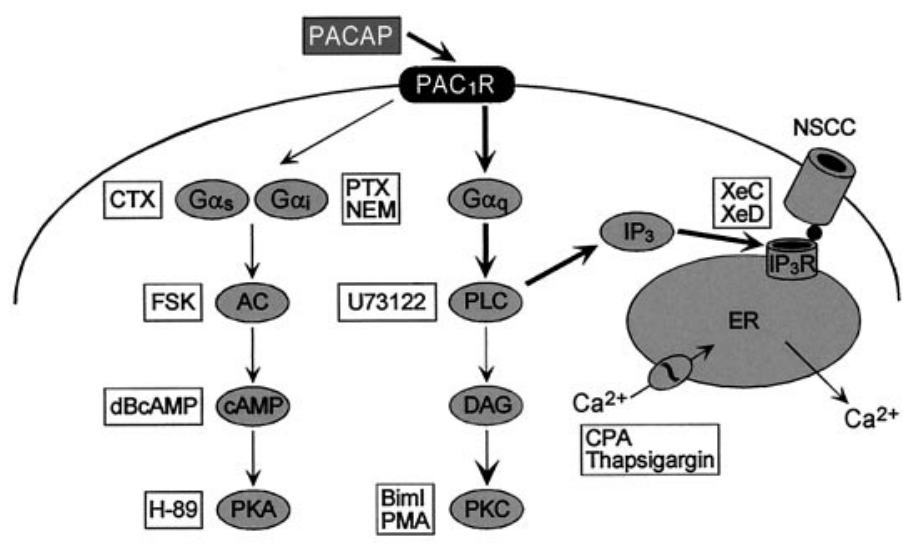

Figure 4. Schematic representation of $\mathrm{PAC}_{1}$ receptor intracellular signaling. $\mathrm{PAC}_{1}$ receptors are coupled to $\mathrm{SCG}$ sympathetic neurons adenylyl cyclase and PLC, resulting in diverse intracellular signaling responses. Second messenger pathway activators and inhibitors used to elucidate the signaling mechanisms underlying the PACAP-induced depolarization are indicated in boxes. The data suggested that PACAP-induced stimulation of $\mathrm{IP}_{3}$ production results in $\mathrm{IP}_{3}$ receptor activation; activated $\mathrm{IP}_{3}$ receptors may directly gate a nonselective cationic conductance, postulated to be a mammalian Trp family channel. $P A C_{1} R$, PACAP-selective, $\mathrm{PAC}_{1}$ receptor; $C T X$, cholera toxin; FSK, forskolin; $d B C A M P$, dibutyryl cAMP; PTX pertussis toxin; NEM, $N$-ethylmaleimide; BimI, bisindolylmaleimide I; $P M A$, phorbol myristate acetate; $C P A$, cyclopiazonic acid; $X e D$, xestospongin $\mathrm{D} ; \mathrm{XeC}$, xestospongin $\mathrm{C} ; I_{3} R, \mathrm{IP}_{3}$ receptor; $N S C C$, nonselective cationic conductance; $A C$, adenylyl cyclase; $P K A$, protein kinase A; PLC, phospholipase $C ; D A G$, diacylglycerol; $P K C$, protein kinase $C$.

gler et al., 1993; Journot et al., 1995; Braas and May, 1996, 1999; Lu et al., 1998). To investigate the potential roles of $\mathrm{G} \alpha$ s, SCG neurons were treated with $500 \mathrm{ng} / \mathrm{ml}$ CTX for $12-15 \mathrm{hr}$ to downregulate $\mathrm{G} \alpha_{\mathrm{s}}$ subunits (Murayama and Ui, 1984; Kaziro et al., 1991); chronic CTX treatment did not inhibit PACAP-induced depolarization in any of the cells examined (Table 3 ). In evaluating the potential roles of $\mathrm{G} \alpha_{\mathrm{i} / \mathrm{o}}$, superfusion of cultured sympathetic neurons with the sulfhydryl alkylating agent NEM $(50 \mu \mathrm{M})$, shown previously to selectively target $\mathrm{G} \alpha_{\mathrm{i} / \mathrm{o}}$ (Shapiro et al., 1994), had no effect on membrane potential and did not occlude the PACAP-initiated depolarizations in SCG neurons (Table 3). Additionally, selective ADP-ribosylation of cellular $\mathrm{G} \alpha_{\mathrm{i} / \mathrm{o}}$ subunits by treatment with 500 $\mathrm{ng} / \mathrm{ml}$ PTX for $12-15 \mathrm{hr}$ also failed to attenuate the peptideinduced depolarizations (Table 3). Hence it appeared that neither $\mathrm{G} \alpha_{\mathrm{s}}$ nor $\mathrm{G} \alpha_{\mathrm{i} / \mathrm{o}}$ mediated the $\mathrm{SCG} \mathrm{PAC}_{1}$ receptor-induced depolarizations.

\section{PACAP-induced SCG neuron depolarizations are not mediated by activation of protein kinase $A$ or protein kinase C}

Subsequent studies tested the potential involvement of the cAMP/ protein kinase A (PKA) pathway in generating the PACAPinduced depolarizations using activators or inhibitors of this signaling cascade. Inhibition of SCG neuron PKA with the selective kinase inhibitor H-89 $(25 \mu \mathrm{M})$ had no apparent effects on the depolarizations (Table 3 ). In addition, neither direct activation of adenylyl cyclase by forskolin $(10 \mu \mathrm{M})$ nor application of the cAMP analogs, dBcAMP (1 mM) or 8-Br-cAMP (1 mM), simulated the PACAP-induced depolarizations (data not shown). Furthermore, pretreatment of sympathetic neurons with either forskolin or dBcAMP did not affect the magnitude of the PACAP-mediated depolarizations (Table 3). These observations indicated that the depolarizations elicited by PACAP were not mediated by the generation of cAMP or subsequent activation of PKA.

To investigate the potential roles of PLC activation by PACAP in eliciting sympathetic neuron depolarizations, cells were pretreated with the PLC inhibitor U73122. Pretreatment of cells with $5.6 \mu \mathrm{M}$ U73122 for $20 \mathrm{~min}$ reduced the PACAP-induced depolarizations $>90 \%$ (1.1 $\pm 0.5 \mathrm{mV} ; n=7 ; p<0.001)$ (Table 3). These results suggested that PLC activation was critical for the PACAP-induced
Table 3. Effects of second messenger activators or inhibitors on PACAPinduced neuron depolarizations

\begin{tabular}{lll} 
Treatment & $\begin{array}{l}\text { Membrane } \\
\text { potential } \\
(\mathrm{mV})\end{array}$ & $\begin{array}{l}\text { PACAP-induced } \\
\text { depolarizations } \\
(\mathrm{mV})\end{array}$ \\
\hline Vehicle, water & $-56 \pm 2$ & $12.9 \pm 0.9(14)$ \\
NEM $(50 \mu \mathrm{M})$ & $-56 \pm 3$ & $12.5 \pm 0.7(8)$ \\
PTX $(500 \mathrm{ng} / \mathrm{ml})$ & $-59 \pm 3$ & $14.6 \pm 1.2(10)$ \\
CTX $(500 \mathrm{ng} / \mathrm{ml})$ & $-64 \pm 4$ & $13.5 \pm 1.4(6)$ \\
dBcAMP $(1 \mathrm{mM})$ & $-54 \pm 1$ & $11.5 \pm 0.5(4)$ \\
Vehicle, DMSO & $-54 \pm 10$ & $15.6 \pm 1.3(10)$ \\
Forskolin $(10 \mu \mathrm{M})$ & $-59 \pm 3$ & $11.5 \pm 1.2(4)$ \\
H-89 $(25 \mu \mathrm{M})$ & $-56 \pm 5$ & $12.4 \pm 1.9(5)$ \\
U73122 $(5.6 \mu \mathrm{M})$ & $-46 \pm 1$ & $1.1 \pm 0.5(7)^{*}$ \\
Biml $(2.5 \mu \mathrm{M})$ & $-58 \pm 3$ & $13.3 \pm 1.5(6)$ \\
PMA $(500 \mathrm{nM})$ & $-52 \pm 8$ & $11.0 \pm 0.6(3)$ \\
XeD $(20 \mu \mathrm{M})$ & $-52 \pm 5$ & $7.6 \pm 1.2(10)^{*}$ \\
XeC $(10 \mu \mathrm{M})$ & $-47 \pm 3$ & $7.7 \pm 1.8(3)^{*}$ \\
\hline
\end{tabular}

SCG neurons in vitro were incubated in defined medium containing the indicated drugs as described in Materials and Methods. The effects of these agents on PACAP27induced depolarization (pressure application) were examined in the presence of $300 \mathrm{~nm}$ TTX. The data represent the mean membrane potential or depolarization \pm SEM, and the numbers of cells tested under each paradigm are shown in parentheses. *Significantly different from vehicle control $(p<0.05)$. The resting membrane potential of neurons in Krebs' solution in the absence of TTX was $-55 \pm 1 \mathrm{mV}(\mathrm{n}=35)$; PACAP27-induced depolarization in these cells was $12.6 \pm 0.7 \mathrm{mV}$.

depolarizations. Additional experiments were conducted to test whether the PACAP-mediated depolarizations were secondary to either diacylglycerol (DAG) production or protein kinase C (PKC) activation, or both (Chyb et al., 1999). The effects of the membranepermeable DAG analog OAG was examined to determine whether the PACAP-induced production of DAG was potentially involved in the generation of the sympathetic neuron depolarizations. Superfusion of 100 or $200 \mu \mathrm{M}$ OAG did not elicit depolarization in any cells tested $(n=5)$; additionally, pretreatment with OAG did not occlude the depolarizations elicited by PACAP (data not shown). The results suggested that PACAP-stimulated generation of DAG does not directly mediate the depolarizations. Subsequently, SCG neurons were treated with PMA acutely to activate PKC; alternatively, sympathetic neurons were chronically treated with PMA to downregulate PKC, or cells were exposed to the PKC inhibitor BimI $(2.5 \mu \mathrm{M})$ before PACAP application. Acute treatment of cells with $500 \mathrm{~nm}$ PMA did not mimic the PACAP-induced depolarizations (data not shown); similarly, neither pretreatment of cells with PMA for 12-16 hr to downregulate PKC protein levels nor incubation with the PKC inhibitor BimI had an effect on the depolarizations (Table 3).

\section{A component of the SCG PACAP-induced depolarizations is mediated by the $\mathrm{IP}_{3}$ receptor}

The preceding results indicated that neither PKC activation nor DAG generation were involved in the PACAP-induced depolarization. Additional experiments tested whether PACAP-stimulated $\mathrm{IP}_{3}$ production might be involved (Fig. 4). Recently, several cellpermeant xestospongin compounds have been described that inhibit $\mathrm{IP}_{3}$ receptors (Gafni et al., 1997). Among these reagents, XeD and $\mathrm{XeC}$ were pharmacologically active at micromolar concentrations, with $\mathrm{XeC}$ demonstrating greater potency between the two compounds. These compounds were used to investigate potential roles of $\mathrm{IP}_{3}$ in the generation of the depolarizations induced by PACAP. Pretreatment of SCG neurons with XeD $(20 \mu \mathrm{M})$ or XeC $(10 \mu \mathrm{M})$ for 20 min decreased the PACAP-elicited depolarizations $51 \%(p<0.001 ; p=0.012$, respectively) (Table 3 ).

To investigate whether calcium ions released from intracellular stores in response to PACAP-stimulated $\mathrm{IP}_{3}$ production and subsequent $\mathrm{IP}_{3}$ receptor activation elicited the peptide-mediated depolarizations, SCG neurons were pretreated with $10 \mu \mathrm{M} \mathrm{CPA}$ or $100 \mathrm{~nm}$ thapsigargin to inhibit the endoplasmic reticulum calcium 
Table 4. Effects of modulation of intracellular calcium stores on PACAPinduced neuron depolarization

\begin{tabular}{lll} 
Treatment & $\begin{array}{l}\text { Membrane } \\
\text { potential } \\
(\mathrm{mV})\end{array}$ & $\begin{array}{l}\text { PACAP-induced } \\
\text { depolarization } \\
(\mathrm{mV})\end{array}$ \\
\hline Vehicle & $-54 \pm 10$ & $15.6 \pm 1.3(10)$ \\
Thapsigargin $(100 \mathrm{nM})$ & $-56 \pm 6$ & $16.3 \pm 1.3(4)$ \\
CPA $(10 \mu \mathrm{M})$ & $-56 \pm 3$ & $13.3 \pm 1.4(7)$ \\
BAPTA $(10 \mu \mathrm{M})$ & $-51 \pm 3$ & $13.0 \pm 1.1(4)$ \\
\hline
\end{tabular}

Sympathetic neurons were incubated in defined medium containing $100 \mathrm{~nm}$ thapsigargin, $10 \mu \mathrm{M}$ CPA, or $10 \mu \mathrm{M}$ BAPTA for $30 \mathrm{~min}$ as described in Materials and Methods. The effects of these agents on PACAP27-induced depolarization (pressure application) was examined in the presence of $300 \mathrm{~nm}$ TTX; for all of the treatments, the drug vehicle was DMSO. The data represent the mean membrane potential or depolarization \pm SEM. The numbers of neurons tested under each paradigm are shown in parentheses.

ATPase, thus allowing internal cellular calcium stores to deplete progressively. CPA or thapsigargin alone did not alter the resting potential of the sympathetic neurons; in addition, neither CPA nor thapsigargin pretreatment diminished the PACAP-induced membrane depolarizations (Table 4). PACAP-stimulated depolarizations were also examined in cells loaded with the calcium chelator BAPTA, which efficiently buffers transient elevations of intracellular calcium (Neher, 1998). Pretreatment of the sympathetic neurons with BAPTA/AM $(10 \mu \mathrm{M})$, the membrane-permeable form of the calcium chelator, had no effect on the magnitude of the PACAP-induced depolarizations (Table 4). On the basis of these observations, we conclude that release of calcium from $\mathrm{IP}_{3}$ sensitive stores was not involved in the generation of the PACAPinduced depolarization. Thus, we hypothesized that the $\mathrm{IP}_{3}$ induced component of the PACAP-induced depolarizations resulted from direct coupling of $\mathrm{IP}_{3}$ receptor activation to an ionic conductance in the plasma membrane.

\section{SCG neuronal expression of specific Trp channels may mediate PACAP-induced currents}

Recent studies suggest that $\mathrm{IP}_{3}$ can engage a subfamily of mammalian Trp channels, thus activating a nonselective cationic conductance (Hu et al., 1994; Dong et al., 1995; Kiselyov et al., 1998). For some Trp subtypes, $\mathrm{IP}_{3}$ receptor occupancy and interactions with Trp to maintain channels in the active state could be attenuated markedly after xestospongin treatment (Kiselyov et al., 1998). At least one Trp isoform has been described to be activated directly by $\mathrm{IP}_{3}$ (Hu et al., 1994; Dong et al., 1995). To evaluate whether Trp-related molecules exist in the SCG and, importantly, whether specific Trp channels shown to be store independent are found in sympathetic neurons to potentially represent PACAP-activated cationic conductances, RT-PCR experiments were undertaken. Using oligonucleotide primers directed against the seven mammalian Trp cDNAs identified to date, all Trp1-Trp7 channels were identified in brain (Fig. 5). By contrast, rat sympathetic neurons demonstrated a different pattern of Trp channel expression. Using our cultures enriched in postganglionic neurons, Trp1, Trp3, Trp6, and Trp7 were well expressed; Trp2, Trp4, and Trp 5 mRNA expression was either low or undetectable. These observations indicated expression of mammalian Trp channels in the SCG; the expression of Trp3, Trp6, and Trp7 in sympathetic neurons is significant because the channels belong to a subfamily characterized by store-independent activation and low cationic specificity.

\section{DISCUSSION}

Studies have suggested that VIP or VIP-related molecules may be noncholinergic modulators of SCG function (Ip et al., 1982, 1983, 1985; Schwarzschild et al., 1989; Zigmond et al., 1989). Recent studies have shown that many of the sympathetic neuron responses described for VIP appear to be mediated largely by PACAP peptides. Both PACAP27 and PACAP38 stimulated with high potency and efficacy SCG neuron transmitter production and se- cretion, second messenger production, and differentiation (May and Braas, 1995; Braas and May, 1996; Lu et al., 1998, 1999). Considerably higher concentrations of VIP were necessary to elicit sympathetic neurosecretion, which appeared consistent with the preferential expression of PACAP-selective $\mathrm{PAC}_{1}$ receptor expression by sympathetic neurons. Sympathetic preganglionic neurons in the intermediolateral cell column of the spinal cord projecting to the SCG express PACAP mRNA (Beaudet et al., 1998), and transection of the cervical sympathetic trunk diminished PACAPimmunoreactive fibers in the SCG (Sundler et al., 1996). In sum, these results presented strong anatomical and physiological evidence implicating PACAP peptides as potential noncholinergic regulators of sympathetic function. The present studies analyzed the direct effects of PACAP peptides on SCG neurons. Using electrophysiological and pharmacological approaches, the studies evaluated PACAP modulation of sympathetic neuron membrane potentials and investigated potential ionic mechanisms and intracellular signaling mechanisms mediating the PACAP-induced depolarizations.

Nearly all of the sympathetic neurons examined exhibited PACAP27- or PACAP38-elicited depolarizations when we used the same SCG neuron system as in our previous regulatory studies (May et al., 1995; May and Braas, 1995; Braas and May, 1996, 1999). The PACAP-induced depolarizations remained when stimulated release was blocked with either TTX or cadmium, demonstrating that the depolarizations represented direct peptidergic effects on sympathetic neurons and were not mediated by interneuronal signaling molecules within the in vitro preparation. The depolarizations mediated by PACAP27 were blunted by the peptide antagonist PACAP(6-38), demonstrating the specificity of the peptide responses; PACAP(6-38) did not inhibit the PACAP38induced depolarizations, a difference that may be related to sympathetic neuron expression of specific $\mathrm{PAC}_{1}$ receptor isoforms. Similarly, PACAP $(6-38)$ was unable to inhibit depolarization of rat sympathetic preganglionic neurons induced by PACAP38 (Lai et al., 1997). PACAP27 and PACAP38 exhibited equal high potency in sympathetic neuron depolarization, whereas VIP had no apparent effects at the concentrations tested. These results were in agreement with investigations establishing the preferential expression of the PACAP-selective $\mathrm{PAC}_{1}$ (short)HOP1 receptor splice variant in rat SCG postganglionic neurons (Lu et al., 1998; Braas and May, 1999). $\mathrm{PAC}_{1}$ receptor mRNA and protein were identified in $>90 \%$ of sympathetic neurons by in situ hybridization histochemistry and immunocytochemistry, respectively (Moller et al., 1997a,b; Nogi et al., 1997; Braas and May, 1999). The potencies of PACAP27 and PACAP38 in eliciting depolarizations were similar to those required for sympathetic neuron second messenger production and neurotransmitter/neuropeptide secretion (May and Braas, 1995; Braas and May, 1999).

The present results indicated that the PACAP-induced inward currents and resultant depolarizations in sympathetic postganglionic neurons required extracellular sodium, demonstrating that the influx of sodium ions is a key component of the currents. Similar to many other neuropeptide-induced depolarizations, sodium influx may be mediated by nonselective cationic channels. PACAPinduced currents also were reduced after elevation of extracellular potassium levels, a result that is consistent with inhibition of a potassium current activated at $-50 \mathrm{mV}$ contributing to the PACAP-induced depolarization. Therefore, at $-50 \mathrm{mV}$ the PACAP-induced inward currents are mediated by a combination of inhibition of a potassium conductance and activation of a sodiumpermeable channel.

We have not identified the potassium conductance contributing to the PACAP-induced depolarizations; however, one potassium conductance commonly inhibited by neuropeptides and other transmitters in rat SCG is the voltage-dependent, noninactivating conductance $I_{M}$ (Brown, 1988). Cruzblanca et al. (1998) demonstrated that bradykinin-induced inhibition of $I_{\mathrm{M}}$ required PLC activation and calcium release from $\mathrm{IP}_{3}$-sensitive stores in acutely dissociated adult SCG neurons. Thus, a component of the PACAPinduced currents was anticipated to be caused by calcium- 
SCG Neurons
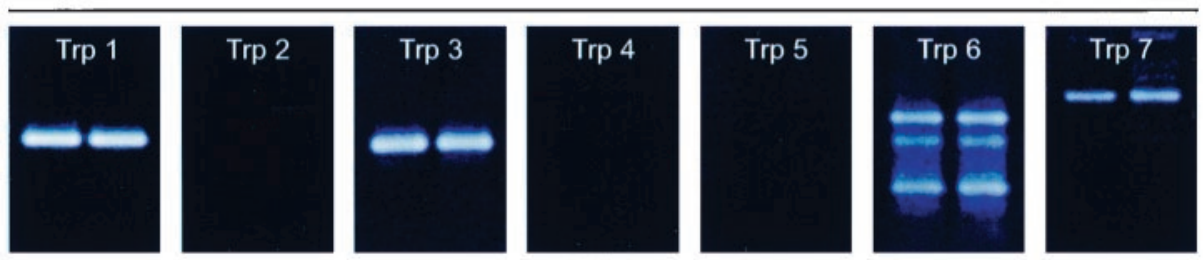

bp

$=800$

$-600$

$-400$

$-200$
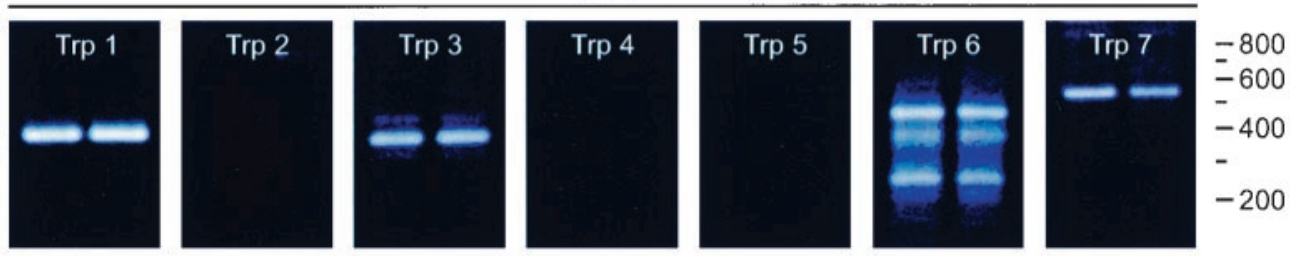

Brain
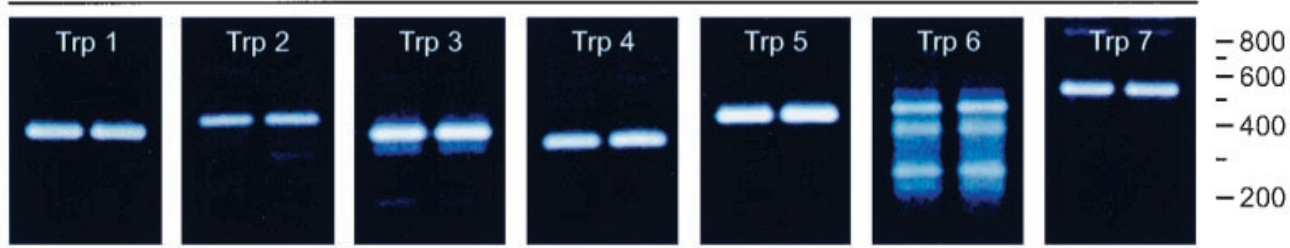

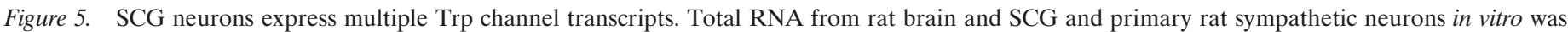

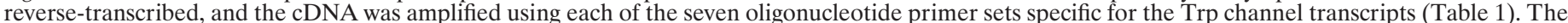

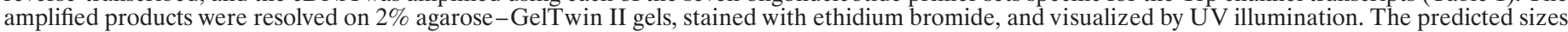

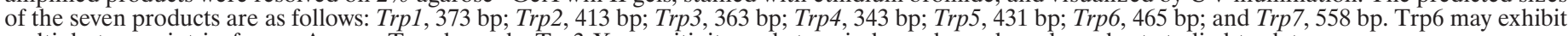
multiple transcript isoforms. Among Trp channels, Trp3 Xe sensitivity and store independence have been best studied to date.

dependent inhibition of $I_{\mathrm{M}}$. However, the lack of thapsigargin, CPA, or BAPTA effects on the PACAP-induced depolarizations strongly indicated that release of calcium from intracellular stores was not required for initiating the PACAP-induced depolarizations. Although a membrane-delimited inhibition of $I_{\mathrm{M}}$ could have been involved in the generation of the depolarizations, preliminary results indicated that this conductance did not represent a significant component of the PACAP-induced currents. Pretreatment of sympathetic neurons voltage-clamped to $-50 \mathrm{mV}$ with $1 \mathrm{~mm}$ barium, a concentration that effectively inhibits $I_{\mathrm{M}}$ (Constanti and Brown, 1981), did not significantly reduce the PACAP-mediated inward currents $(<5 \%)$ (M. M. Beaudet, unpublished observation). Given the voltage dependence of $I_{\mathrm{M}}$, i.e., that only a small portion of $I_{\mathrm{M}}$ conductance would be activated at $-50 \mathrm{mV}$, inhibition of $I_{\mathrm{M}}$ under these recording conditions would not be expected to be a prominent contributor to the PACAP-induced currents.

SCG neurons express preferentially PACAP-selective PAC $_{1}$ (short) HOP1 receptor variants that demonstrate potent and efficacious stimulation of cAMP and inositol phosphate production by PACAP27 and PACAP38 (Lu et al., 1998; Braas and May, 1999). Studies using bacterial toxins, and intracellular second messenger activators or inhibitors indicated that the $\mathrm{CAMP} / \mathrm{PKA}$ pathway did not participate in the generation of the PACAP-induced currents or depolarizations. Because inhibition of PLC attenuated markedly the PACAP-induced depolarizations, PLC-dependent $\mathrm{IP}_{3}$ or DAG production appeared to be important for the generation of the peptide-induced depolarizations. However, application of OAG did not elicit membrane depolarizations, and inhibition of PKC did not affect the PACAP-induced depolarizations, suggesting that synthesis of DAG did not contribute to the responses.

By contrast, inhibition of $\mathrm{IP}_{3}$ receptors suggested that $\mathrm{IP}_{3}$ production was crucial to the peptide-induced depolarizations. However, neither depletion of calcium stores nor intracellular calcium chelation affected the PACAP-induced membrane depolarizations, suggesting that calcium release from $\mathrm{IP}_{3}$-sensitive stores was not required for the responses. Rather, the depolarizations appeared to depend on direct $\mathrm{IP}_{3}$-mediated modulation of an ionic conduc- tance in the plasma membrane. Direct $\mathrm{IP}_{3}$ activation of nonselective cationic conductances has been reported for a number of cell types, including lymphocytes, cerebellar Purkinje cells, and vascular endothelial cells (Kuno and Gardner, 1987; Mozhayeva et al., 1990; Brent et al., 1993; McDonald et al., 1993; Kuno et al., 1994; Vaca and Kunze, 1995), and therefore could be involved in the generation of the PACAP-induced depolarizations of SCG neurons.

Many molecular, biochemical, and electrophysiological studies have suggested that Trp, Trpl, and other Trp-related molecules, first identified by Drosophila genetics, function as membrane ion channels (Birnbaumer et al., 1996; Zhu et al., 1996; Montell, 1997; Philipp et al., 1998; Okada et al., 1998, 1999). Congruous with the presented data, activation of a nonselective cationic conductance of the Trp family could be a component of the depolarization of SCG neurons elicited by PACAP. Several Trp channel members demonstrate characteristics consistent with our observations. Among the seven mammalian Trp channels identified to date, Trp3, Trp6, and Trp7 from recombinant expression demonstrate relatively low selectivity for divalent and monovalent cations. Contrary to early suggestions, not all members of the Trp family of channels are activated simply after calcium store depletion, and the Trp3, Trp6, and Trp7 subfamily has been shown to be store independent (Okada et al., 1999). The mechanisms of Trp channel activation have not been completely elucidated, but recent studies have supported the $\mathrm{IP}_{3}$ receptor conformational coupling hypothesis with Trp for sustained channel activation (Kiselyov et al., 1998; Boulay et al., 1999; Zubov et al., 1999). $\mathrm{IP}_{3}$ receptor-mediated activation of the human Trp homolog HTrp3 for example, can be blocked by heparin and xestospongin $\mathrm{IP}_{3}$ receptor inhibition (Kiselyov et al., 1998), and $\mathrm{IP}_{3}$ receptors can be coimmunoprecipitated with HTrp3 channels. These properties are similar to our experimental results. PACAP activation of sympathetic neuron $\mathrm{PAC}_{1}$ receptors potently stimulates PLC activity and $\mathrm{IP}_{3}$ production, and inhibition of PLC or $\mathrm{IP}_{3}$ receptors attenuated the depolarizations, supporting the contention that $\mathrm{IP}_{3}$-mediated activation of a nonselective cationic conductance contributes to the responses. Furthermore, depolar- 
ization occurred in the absence of intracellular calcium release, and sympathetic postganglionic neuron expression of Trp channel transcripts is consistent with direct $\mathrm{IP}_{3} / \mathrm{IP}_{3}$ receptor interaction with these channel proteins. Although several members of the Trp3 channel family are activated directly by DAG (Hofmann et al., 1999; Okada et al., 1999), OAG did not depolarize these sympathetic neurons, results inconsistent with DAG-operated channel involvement in the PACAP-generated depolarization. However, our present results do not rule out a DAG metabolite in the generation of a component of the PACAP-induced depolarizations (Chyb et al., 1999).

We considered that the residual inward current recorded with elevated potassium and sodium-deficient NMG-substituted solution might have been produced by calcium influx. However, in a calcium-deficient solution, the residual current amplitude was not diminished but enhanced nominally. From these observations, calcium influx did not appear to contribute significantly to the PACAP-induced currents under these experimental conditions. Also, raising extracellular calcium inhibited the PACAP-induced current. The current amplitude was decreased when the external calcium concentration was raised twofold; similarly, increasing external calcium levels twofold decreased the inward sodium current recorded at $-50 \mathrm{mV}$ in neurons maintained in HEPESbuffered sodium solution with elevated $\mathrm{KCl}$. These results were consistent with the previously described calcium-mediated inactivation of some Trp channels in vitro (Montell, 1997; Okada et al., 1999).

In summary, the present electrophysiological studies demonstrated that $>90 \%$ SCG sympathetic neurons are depolarized after PACAP activation of PAC $_{1}$ receptors. The PACAP-induced depolarizations were mediated by concomitant activation of sodium influx and inhibition of a potassium current. The depolarizations required PLC activation and subsequent $\mathrm{IP}_{3}$ production. Given the selective expression of Trp3, Trp6, and Trp7 family members in sympathetic neurons, these studies support $\mathrm{PAC}_{1}$ receptormediated $\mathrm{IP}_{3}$ receptor activation of a nonselective cationic conduction potentially related to a mammalian Trp.

\section{REFERENCES}

Absood A, Chen D, Hakanson R (1992) Neuropeptides of the vasoactive intestinal peptide/helodermin/pituitary adenylate cyclase activating peptide family elevate plasma cAMP in mice: comparison with a range of other regulatory peptides. Regul Pept 40:311-322.

Arimura A (1998) Perspectives on pituitary adenylate cyclase activating polypeptide (PACAP) in the neuroendocrine, endocrine, and nervous systems. Jpn J Physiol 48:301-331.

Arimura A, Shioda S (1995) Pituitary adenylate cyclase activating polypeptide (PACAP) and its receptors: neuroendocrine and endocrine interaction. Front Neuroendocrinol 16:53-88.

Beaudet MM, Braas KM, May V (1998) Pituitary adenylate cyclase activating polypeptide (PACAP) expression in sympathetic preganglionic projection neurons to the superior cervical ganglion. J Neurobiol 36:325-336.

Birnbaumer L, Zhu X, Jiang M, Boulay G, Peyton M, Vannier B, Brown D, Platano D, Sadeghi H, Stefani E, Birnbaumer M (1996) On the molecular basis and regulation of cellular capacitative calcium entry: roles for Trp proteins. Proc Natl Acad Sci USA 93:15195-15202.

Boulay G, Brown DM, Qin N, Jiang M, Dietrich A, Zhu MX, Chen Z, Birnbaumer M, Mikoshiba K, Birnbaumer L (1999) Modulation of $\mathrm{Ca}^{2+}$ entry by polypeptides of the inositol 1,4,5-trisphophate receptor (IP3R) that bind transient receptor potential (TRP): evidence for roles of TRP and IP3R in store depletion-activated $\mathrm{Ca}^{2+}$ entry. Proc Natl Acad Sci USA 96:14955-14960.

Braas KM, May V (1996) Pituitary adenylate cyclase-activating polypeptides, PACAP-38 and PACAP-27, regulation of sympathetic neuron catecholamine, and neuropeptide Y expression through activation of type I PACAP/VIP receptor isoforms. Ann NY Acad Sci 805:204-216.

Braas KM, May V (1999) Pituitary adenylate cyclase-activating polypeptides directly stimulate sympathetic neuron neuropeptide Y release through $\mathrm{PAC}_{1}$ receptor isoform activation of specific intracellular signaling pathways. J Biol Chem 274:27702-27710.

Braas KM, May V, Harakall SA, Hardwick JC, Parsons RL (1998) Pituitary adenylate cyclase-activating polypeptide expression and modulation of neuronal excitability in guinea pig cardiac ganglia. J Neurosci 18:9766-9779.

Brent LH, Gong Q, Ross JM, Wieland SJ (1993) Mitogen-activated Ca ${ }^{++}$ channels in human B lymphocytes. J Cell Physiol 155:520-529.

Brown D (1988) M-currents: an update. Trends Neurosci 11:294-299.
Christophe J (1993) Type I receptors for PACAP (a neuropeptide even more important than VIP?). Biochim Biophys Acta 1154:183-199.

Chyb S, Raghu P, Hardie RC (1999) Polyunsaturated fatty acids activate the Drosophila light-sensitive channels TRP and TRPL. Nature 397:255-259.

Constanti A, Brown DA (1981) M-currents in voltage-clamped mammalian sympathetic neurones. Neurosci Lett 24:289-294.

Cruzblanca H, Koh DS, Hille B (1998) Bradykinin inhibits M current via phospholipase $\mathrm{C}$ and $\mathrm{Ca}^{2+}$ release from $\mathrm{IP}_{3}$-sensitive $\mathrm{Ca}^{2+}$ stores in rat sympathetic neurons. Proc Natl Acad Sci USA 95:7151-7156.

Deutsch PJ, Sun Y (1992) The 38-amino acid form of pituitary adenylate cyclase-activating polypeptide stimulates dual signaling cascades in PC12 cells and promotes neurite outgrowth. J Biol Chem 267:5108-5113.

DiCicco-Bloom E (1996) Region-specific regulation of neurogenesis by VIP and PACAP: direct and indirect modes of action. Ann NY Acad Sci 805:244-256.

DiCicco-Bloom E, Deutsch P (1992) Pituitary adenylate cyclase activating polypeptide (PACAP) potently stimulates mitosis, neuritogenesis and survival in cultured rat sympathetic neuroblasts. Regul Pept 37:319.

Dong Y, Kunze DL, Vaca L, Schilling WP (1995) Ins(1,4,5)P3 activates Drosophila cation channel Trpl in recombinant baculovirus-infected Sf9 insect cells. Am J Physiol 269:C1332-1339.

Gafni J, Munsch JA, Lam TH, Catlin MC, Costa LG, Molinski TF, Pessah IN (1997) Xestospongins: potent membrane permeable blockers of the inositol 1,4,5-trisphosphate receptor. Neuron 19:723-733.

Harmar T, Lutz E (1994) Multiple receptors for PACAP and VIP. Trends Pharmacol Sci 15:97-99.

Hashimoto H, Ishihara T, Shigemoto R, Mori K, Nagata S (1993) Molecular cloning and tissue distribution of a receptor for pituitary adenylate cyclase-activating polypeptide. Neuron 11:333-342.

Hofmann T, Obukhov AG, Schaefer M, Harteneck C, Gudermann T, Schultz G (1999) Direct activation of human TRPC6 and TRPC3 channels by diacylglycerol. Nature 397:259-263.

Hu Y, Vaca L, Zhu X, Birnbaumer L, Kunze DL, Schilling WP (1994) Appearance of a novel $\mathrm{Ca}^{2+}$ influx pathway in Sf9 insect cells following expression of the transient receptor potential-like (trpl) protein of Drosophila. Biochem Biophys Res Commun 201:1050-1056.

Ip NY, Ho CK, Zigmond RE (1982) Secretin and vasoactive intestinal peptide acutely increase tyrosine 3-monooxygenase in the rat superior cervical ganglion. Proc Natl Acad Sci USA 79:7566-7569.

Ip NY, Perlman RL, Zigmond RE (1983) Acute transsynaptic regulation of tyrosine 3-monooxygenase activity in the rat superior cervical ganglion: evidence for both cholinergic and noncholinergic mechanisms. Proc Natl Acad Sci USA 80:2081-2085.

Ip NY, Baldwin C, Zigmond RE (1985) Regulation of the concentration of adenosine $3^{\prime}, 5^{\prime}$-cyclic monophosphate and the activity of tyrosine hydroxylase in the rat superior cervical ganglion by three neuropeptides of the secretin family. J Neurosci 5:1947-1954.

Journot L, Waeber C, Pantaloni C, Holsboer F, Seeburg PH, Bockaert J, Spengler D (1995) Differential signal transduction by six splice variants of the pituitary adenylate cyclase-activating peptide (PACAP) receptor. Biochem Soc Trans 23:133-137.

Kawatani M, Rutigliano M, de Groat WC (1985) Depolarization and muscarinic excitation induced in a sympathetic ganglion by vasoactive intestinal polypeptide. Science 229:879-881.

Kaziro Y, Itoh H, Kozasa T, Nakafuku M, Satoh T (1991) Structure and function of signal-transducing GTP-binding proteins. Annu Rev Biochem 60:349-400.

Kiselyov K, Xu X, Mozhayeva G, Kuo T, Pessah I, Mignery G, Zhu X, Birnbaumer L, Muallem S (1998) Functional interaction between InsP3 receptors and store-operated Htrp3 channels. Nature 396:478-482.

Kuno M, Gardner P (1987) Ion channels activated by inositol 1,4,5trisphosphate in plasma membrane of human T-lymphocytes. Nature 326:301-304.

Kuno M, Maeda N, Mikoshiba K (1994) IP $_{3}$-activated calcium-permeable channels in the inside-out patches of cultured cerebellar Purkinje cells. Biochem Biophys Res Commun 199:1128-1135.

Lai CC, Wu SY, Lin HH, Dun NJ (1997) Excitatory action of pituitary adenylate cyclase activating polypeptide on rat sympathetic preganglionic neurons in vivo and in vitro. Brain Res 748:189-194.

Lu N, Zhou R, DiCicco-Bloom E (1998) Opposing mitogenic regulation by PACAP in sympathetic and cerebral cortical precursors correlates with differential expression of PACAP receptor $\left(\mathrm{PAC}_{1}-\mathrm{R}\right)$ isoforms. J Neurosci Res 53:651-662.

May V, Braas KM (1995) Pituitary adenylate cyclase-activating polypeptide (PACAP) regulation of sympathetic neuron neuropeptide $\mathrm{Y}$ and catecholamine expression. J Neurochem 65:978-987.

May V, Brandenburg CA, Braas KM (1995) Differential regulation of sympathetic neuron neuropeptide $\mathrm{Y}$ and catecholamine content and secretion. J Neurosci 15:4580-4591.

May V, Beaudet MM, Parsons RL, Hardwick JC, Gauthier EA, Durda JP, Braas KM (1998) Mechanisms of pituitary adenylate cyclase activating polypeptide (PACAP)-induced depolarization of sympathetic superior cervical ganglion (SCG) neurons. Ann NY Acad Sci 865:164-175.

McDonald TV, Premack BA, Gardner P (1993) Flash photolysis of caged inositol 1,4,5-trisphosphate activates plasma membrane calcium current in human T cells. J Biol Chem 268:3889-3896.

Moller K, Reimer M, Hannibal J, Fahrenkrug J, Sundler F, Kanje M 
(1997a) Pituitary adenylate cyclase-activating peptide (PACAP) and PACAP type 1 receptor expression in regenerating adult mouse and rat superior cervical ganglia in vitro. Brain Res 775:156-165.

Moller K, Reimer M, Ekblad E, Hannibal J, Fahrenkrug J, Kanje M, Sundler F (1997b) The effects of axotomy and preganglionic denervation on the expression of pituitary adenylate cyclase activating peptide (PACAP), galanin and PACAP type 1 receptors in the rat superior cervical ganglion. Brain Res 775:166-182.

Montell C (1997) New light on TRP and TRPL. Mol Pharmacol 52:755-763.

Mozhayeva GN, Naumov AP, Kuryshev YA (1990) Inositol 1,4,5-trisphosphate activates two types of $\mathrm{Ca}^{2(+)}$-permeable channels in human carcinoma cells. FEBS Lett 277:233-234.

Murayama T, Ui M (1984) $\left[{ }^{3} \mathrm{H}\right]$ GDP release from rat and hamster adipocyte membranes independently linked to receptors involved in activation or inhibition of adenylate cyclase. Differential susceptibility to two bacterial toxins. J Biol Chem 259:761-769.

Neher E (1998) Vesicle pools and $\mathrm{Ca}^{2+}$ microdomains: new tools for understanding their roles in neurotransmitter release. Neuron 20:389-399.

Nogi H, Hashimoto H, Hagihara N, Shimada S, Yamamoto K, Matsuda T, Tohyama M, Baba A (1997) Distribution of mRNAs for pituitary adenylate cyclase-activating polypeptide (PACAP), PACAP receptor, vasoactive intestinal polypeptide (VIP), and VIP receptors in the rat superior cervical ganglion. Neurosci Lett 227:37-40.

Okada T, Shimizu S, Wakamori M, Maeda A, Kurosaki T, Takada N, Imoto K, Mori Y (1998) Molecular cloning and functional characterization of a novel receptor-activated TRP $\mathrm{Ca}^{2+}$ channel from mouse brain. J Biol Chem 273:10279-10287.

Okada T, Inoue R, Yamazaki K, Maeda A, Kurosaki T, Yamakuni T, Tanaka I, Shimizu S, Ikenaka K, Imoto K, Mori Y (1999) Molecular and functional characterization of a novel mouse transient receptor potential protein homologue TRP7. J Biol Chem 274:27359-27379.

Philipp S, Hambrecht J, Braslavski L, Schroth G, Freichel M, Murakami M, Cavalie A, Flockerzi V (1998) A novel capacitative calcium entry channel expressed in excitable cells. EMBO J 17:4274-4282.

Rawlings SR, Hezareh M (1996) Pituitary adenylate cyclase-activating polypeptide (PACAP) and PACAP/vasoactive intestinal polypeptide receptors: actions on the anterior pituitary gland. Endocr Rev 17:4-29.

Schofield GG, Ikeda SR (1989) Potassium currents of acutely isolated adult rat superior cervical ganglion neurons. Brain Res 485:205-214.
Schwarzschild MA, Vale W, Corigliano-Murphy AC, Pisano JJ, Ip NY, Zigmond RE (1989) Activation of ganglionic tyrosine hydroxylase by peptides of the secretin-glucagon family: structure-function studies. Neuroscience 31:159-167.

Shapiro MS, Wollmuth LP, Hille B (1994) Modulation of $\mathrm{Ca}^{2+}$ channels by PTX-sensitive G-proteins is blocked by $N$-ethylmaleimide in rat sympathetic neurons. J Neurosci 14:7109-7116.

Shibuya I, Kabashima N, Tanaka K, Setiadji VS, Noguchi J, Harayama N, Ueta Y, Yamashita H (1998) Patch-clamp analysis of the mechanism of PACAP-induced excitation in rat supraoptic neurones. J Neuroendocrinol 10:759-768.

Spengler D, Waeber C, Pantaloni C, Holsboer F, Bockaert J, Seeburg PH, Journot L (1993) Differential signal transduction by five splice variants of the PACAP receptor. Nature 365:170-175.

Sundler F, Ekblad E, Hannibal J, Moller K, Zhang YZ, Mulder H, Elsas T, Grunditz T, Danielsen N, Fahrenkrug J, Uddman R (1996) Pituitary adenylate cyclase-activating peptide in sensory and autonomic ganglia: localization and regulation. Ann NY Acad Sci 805:410-426.

Svoboda M, Tastenoy M, Ciccarelli E, Stievenart M, Christophe J (1993) Cloning of a splice variant of the pituitary adenylate cyclase-activating polypeptide (PACAP) type I receptor. Biochem Biophys Res Commun 195:881-888.

Tanaka J, Koshimura K, Murakami Y, Kato Y (1996) Stimulatory effect of PACAP on neuronal cell survival. Ann NY Acad Sci 805:473-475.

Vaca L, Kunze DL (1995) $\mathrm{IP}_{3}$-activated $\mathrm{Ca}^{2+}$ channels in the plasma membrane of cultured vascular endothelial cells. Am J Physiol 269:C733-C738.

Waschek JA (1996) VIP and PACAP receptor-mediated actions on cell proliferation and survival. Ann NY Acad Sci 805:290-300.

Zhu X, Jiang M, Peyton M, Boulay G, Hurst R, Stefani E, Birnbaumer L (1996) trp, a novel mammalian gene family essential for agonistactivated capacitative $\mathrm{Ca}^{2+}$ entry. Cell 85:661-671.

Zigmond RE, Schwarzschild MA, Rittenhouse AR (1989) Acute regulation of tyrosine hydroxylase by nerve activity and by neurotransmitters via phosphorylation. Annu Rev Neurosci 12:415-461.

Zubov AI, Kaznacheeva EV, Nikolaev AV, Alexeenko VA, Kiselyov K, Muallem S, Mozhayeva GN (1999) Regulation of the miniature plasma membrane $\mathrm{Ca}^{2+}$ channel $I_{\min }$ by inositol 1,4,5-trisphosphate receptors.
J Biol Chem 274:25983-25985. 